1992-09-01

\title{
Species of the Cretaceous tree fern Tempskya from Utah
}

William D. Tidwell

Naomi Hebbert

Follow this and additional works at: https://scholarsarchive.byu.edu/facpub

Part of the Geology Commons

\section{Original Publication Citation}

Species of the Cretaceous tree fern Tempskya from Utah. Tidwell, William D. Hebbert, Naomi International Journal of Plant Sciences, Vol. 153, No. 3, (Sep., 1992)

\section{BYU ScholarsArchive Citation}

Tidwell, William D. and Hebbert, Naomi, "Species of the Cretaceous tree fern Tempskya from Utah" (1992). Faculty Publications. 1445.

https://scholarsarchive.byu.edu/facpub/1445 


\title{
SPECIES OF THE CRETACEOUS TREE FERN TEMPSKYA FROM UTAH
}

\author{
WILLIAM D. TIDWELL' ${ }^{i}$ AND NAOMI HEBBERT \\ Department of Botany and Range Science, Brigham Young University, Provo, Utah 84602
}

\begin{abstract}
Nine species of the permineralized stems of Tempskya were investigated from the upper Lower Cretaceous Cedar Mountain and Burro Canyon Formations, and the lower Upper Cretaceous Dakota Formation in central and southeastern Utah. Tempskya jonesii, $T$. stichkae, and $T$. readii are new and are differentiated on the basis of the radial orientation of their dorsiventral stems, their internodal lengths, the lack of sclerenchyma in the inner cortex of $T$. jonesii, the three nearly continuous zones of sclerenchyma in the inner cortex of $T$. stichkae, and the completely sclerotic inner cortex of $T$. readii. Specimens of $T$. jonesii and T. minor were collected in growth position near Castle Dale, Utah, which is the first time Tempskya has been collected in this position in North America. Thin leaves were also observed for the first time in Tempskya in specimens of $T$. wyomingense. Tunnels containing three sizes of fecal pellets are common in tissues of stems, roots, petioles, and epidermal hairs of the false trunks of Tempskya, indicating that three different grazers fed upon these plants. Arbuscules of vesicular-arbuscular (V-A) mycorrhizal fungi occur in some roots of the false trunks of $T$. jonesii. Specific characters of Tempskya and possible environmental circumstances under which these plants grew are reviewed, and we conclude that they grew under relatively humid conditions in swamps on flood plains.
\end{abstract}

\section{Introduction}

Tempskya, named by Corda (1845), is an unusual tree fern which lived during the Cretaceous period. Specimens of this genus consist of false trunks composed of a dichotomous branching stem system which is surrounded by a thick mat of adventitious roots. Although many well-preserved silicified specimens have been studied, many aspects of these plants remain uncertain. Because of this, much speculation has surrounded Tempskya since it was first reported by Stokes and Webb (1824) under the name Endogenites erosa. Since then they have been discovered at many localities in the Northern Hemisphere. Historical accounts about this genus have been published by Read and Brown (1937), Ash and Read (1976), and Hlustik (1990).

Geographically, Tempskya is presently known only from the Northern Hemisphere, where it is restricted generally to the Lower Cretaceous. It occurs in England, Ireland, northern France, Germany, Czechoslovakia, USSR, Japan, and ca. 43 localities in the United States. Most of these localities in the United States are in the Rocky Mountain region in such diverse areas as central Montana, north-central and western Wyoming, southeastern Idaho, east-central Oregon, southwestern Colorado, northeastern Arizona, southern Nevada, northwestern and southwestern New Mexico, and Utah (Ash and Read 1976). Our research on Tempskya has centered on localities in the upper Lower Cretaceous Cedar Mountain and Burro Canyon Formations, and the lower Upper Cretaceous Dakota Formation from central and southeastern Utah (fig. 1). The many

'Author for correspondence and reprints.

Manuscript received October 1991; revised manuscript received January 1992. specimens of Tempskya collected from these formations indicate that this fern grew abundantly in this region at the time the formations were being deposited.

\section{Material and methods}

Specimens of Tempskya are silicified and vary in color from black to gray to red where they had been weathered. Several false trunks have been collected somewhat intact, although most specimens are represented by fragments. The majority of Tempskya specimens from Utah are well preserved; however, some are not. In these, either the stems have disintegrated, leaving cavities in the specimen, or the stem areas have been replaced with white crystalline material. The specimens are striking aesthetically but are inadequate for scientific study.

Specimens of Tempskya have been collected in growth position near Castle Dale, Utah (locality 1), which is rather unusual for these plants (fig. 2). Specimens from the other Utah localities appear to have been transported. Many have been moved only short distances, but they were still collected in a horizontal position rather than a vertical or growth position.

Standard thin-sections and acetate peels were made of the fossils and studied with transmitted light. Some of those permineralized with darker material were etched in $\mathrm{HF}$ and studied using reflected light microscopy.

Portions of two specimens were chemically macerated, and the residue of plant material, particularly the spores, was isolated for study.

Dr. E. M. V. Nambudiri, University of Regina, crushed samples of the carbonaceous (coalified) shale associated with the Tempskya to -20 mesh and mounted the samples as epoxy pellets for petrographic analysis. 


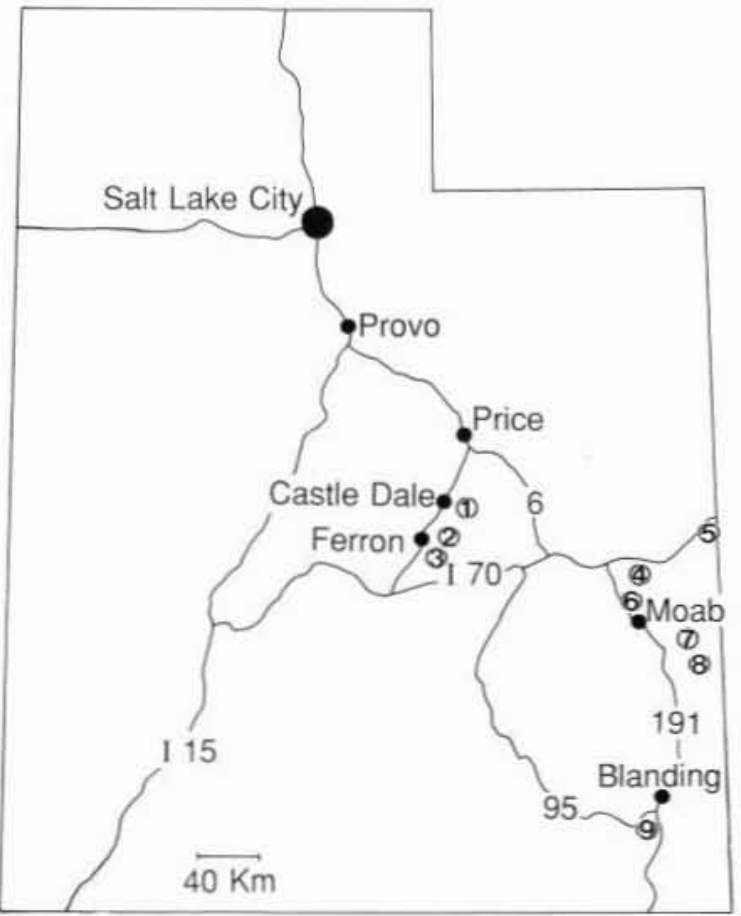

Fig. 1 Index map of Utah showing collecting sites for Tempskya. 1, Castle Dale locality; 2, Ferron locality; 3, south of locality 2; 4, Yellowcat area; 5, Westwater locality; 6, Moab airport locality; 7, Blue Mesa locality; 8, Pack Creek locality; and 9, Cottonwood Creek locality near Blanding.

\section{History of investigations of Utah Tempskya}

Specimens of Tempskya were reported from the Dakota Formation in San Juan County in southeastern Utah by Read and Brown (1937). Brown (1950) described a specimen collected by W. L. Stokes from the Dakota Formation in Grand County, Utah, as T. knowltonii. However, according to Katich (1952), a reassessment of the specimen led Brown to consider placing it in a new species, but this was never accomplished. Tempskya was collected during investigations of the fossil plants of the Dakota Formation in the area (Tidwell et al. 1967; Rushforth and Tidwell 1968; Rushforth 1971). Amateur collectors have also collected a large number of Tempskya specimens in the Yellowcat area (locality 4) in the Cedar Mountain Formation a few miles to the west of where Stokes collected his specimen.

Tempskya has been investigated from the Cedar Mountain Formation near the type locality of this formation at Cedar Mountain, Utah (Katich 1951; Tidwell 1966). Specimens collected by
Stokes (1952) were tentatively identified as $T$. minor Read and those of Katich (1951) as Tempskya sp.

Arnold (1958) mentioned observing Tempskya about $9.6 \mathrm{~km}$ southeast of Castle Dale, Utah, near locality 1 . The bed in which he saw these specimens lies about $15.2 \mathrm{~m}$ below the overlying Dakota Formation in the Cedar Mountain Formation. He tentatively identified them as $T$. minor. We collected five specimens in growth position from this locality, and curators at the Utah State Museum of Natural History collected another. Their specimen is a $1.8 \mathrm{~m}$ high $T$. minor.

Specimens of an unidentified species of Tempskya were reported by McKnight and Rigby (1963) from the upper portion of the Cedar Mountain (Burro Canyon) Formation northwest of Moab at locality 6 (fig. 1). Tidwell and Hebbert (1972, 1976) discussed the occurrence of Tempskya in the Cedar Mountain Formation from localities near Castle Dale (locality 1) and the Moab airport, Utah. In a reevaluation of the tempskyas mentioned from this formation by Tidwell et al. (1976), $T$. jonesii remains a new species in this article; specimens called $T$. whiteheadii are assigned to $T$. wesselii; and those tentatively referred to $T$. superba are here assigned to $T$. wyomingense. Tempskya has also been noted from the Burro Canyon and Dakota Formations southwest of Moab near the La Sal Mountains (locality 8; Read and Brown 1937; Ash and Read 1976).

\section{Localities for Tempskya in Utah}

Nine species of Tempskya were studied from the Cedar Mountain, Burro Canyon, and Dakota Formations in Utah (fig. 1; table 1). These consist of the three new species, $T$. jonesii, $T$. stichkae, and $T$. readii, under consideration and six species, $T$. minor, $T$. zellerii, $T$. wesselii, $T$. wyomingense, $T$. grandis, and $T$. superba, described previously either from Utah or elsewhere in the western United States.

Locality 1. The Castle Dale locality occurs $9.6 \mathrm{~km}$ southeast of Castle Dale, Utah, near the confluence of Cottonwood Creek and Huntington Creek which forms the San Rafael River (SW $1 / 4$, $\mathrm{SE}^{1 / 4}$, Sec. 21, T19S, R9E). This is near Katich's (1951, 1952) locality and the site where Tschudy et al. (1984; USGS KCM D5785) collected the palynomorphs for their study. The Cedar Mountain Formation at this locality is composed of brown to gray shales and sandstones. It contains a horizon of nearly coalified material ca. $50 \mathrm{ft}$

Figs. 2-8 Tempskya jonesii sp. nov. Fig. 2, Three false trunks of $T$. jonesii in growth position at the Castle Dale locality, Senior author at left for scale. Fig. 3, Transverse section of the closest specimen of $T$. jonesii in fig. 2 illustrating the stems and roots. Specimen 5045 ( $\times$.3). Fig. 4, Closeup of stems from fig. 2 showing departing leaf traces. Specimen 5045 ( $\times 8$ ). Fig. 5 , Longitudinal section demonstrating the origin of the dichotomizing stems (arrows) from the base of false trunk in fig. 3. Note 

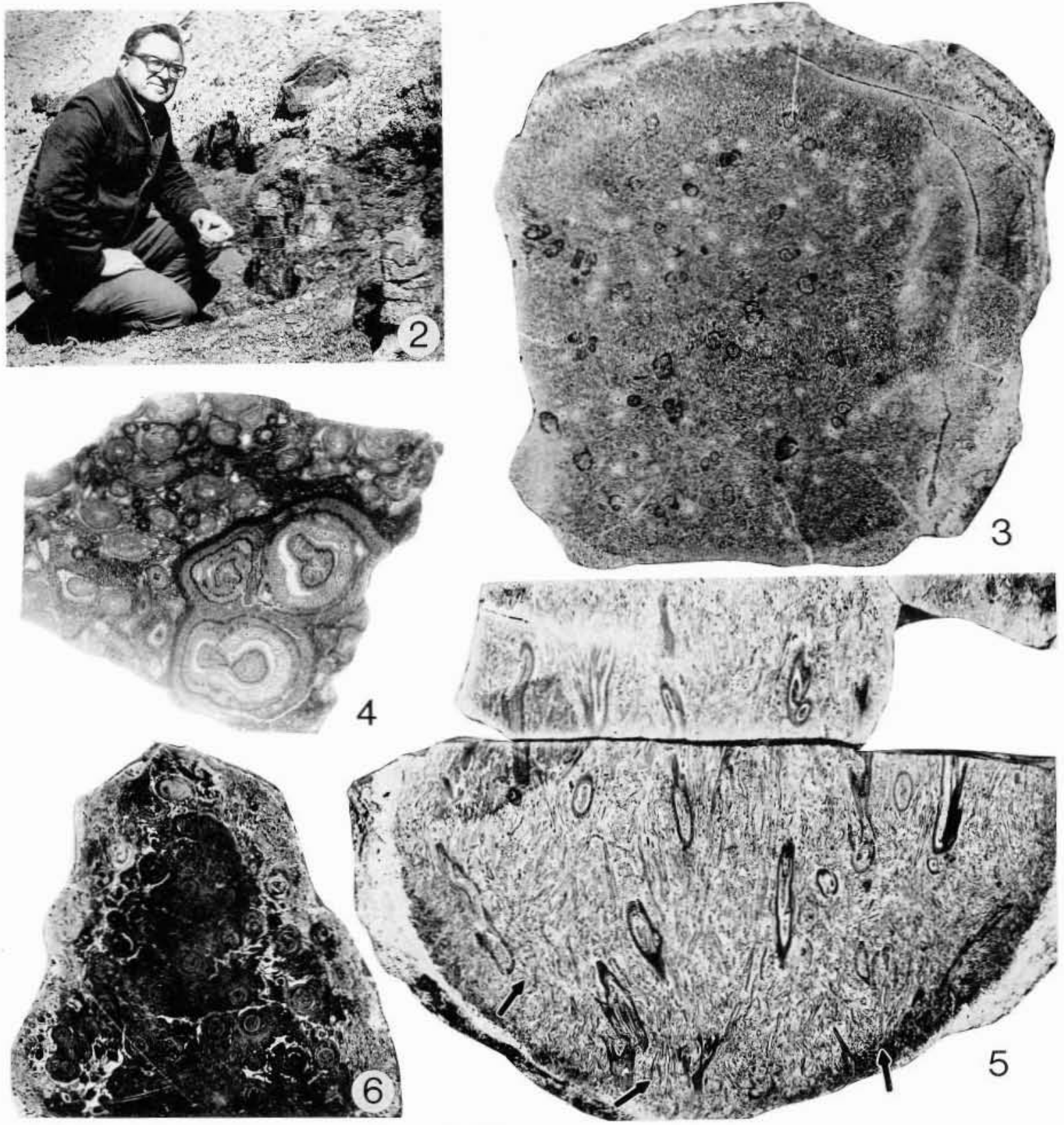

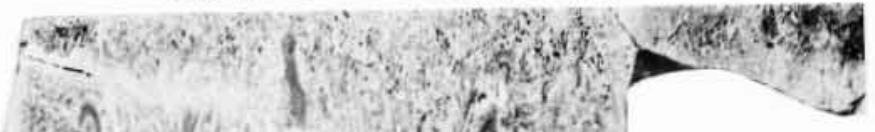

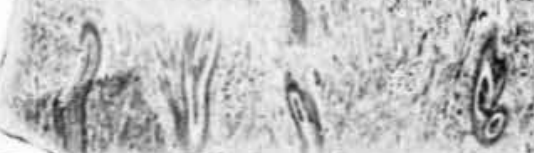
7. 2. a.s. 3.

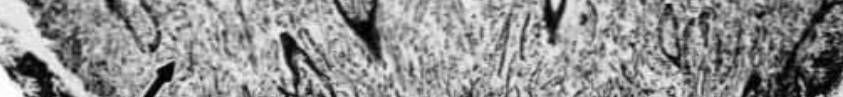

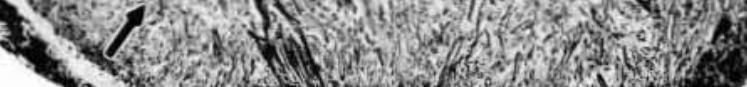
1. 3 (3) -
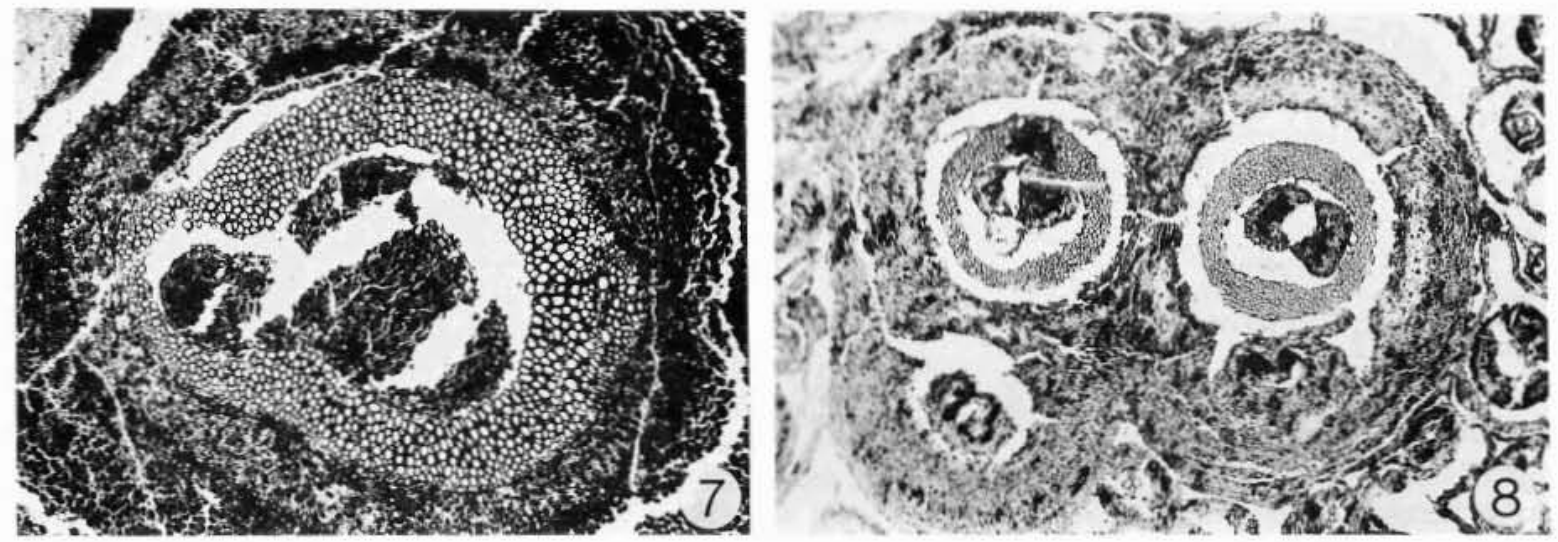

there are at least three separate branching stems visible in this view. Specimen $5045(\times .75)$. Fig. 6, Cross section of the holotype of $T$. jonesii. Specimen $5046(\times 1.1)$. Figs. 7, 8, Closeups of stems of $T$. jonesii in cross section. Specimen $5046(7, \times 25 ; 8$, $\times 12)$. 
Table 1

TEMPSKYA SPECIES FROM UTAH

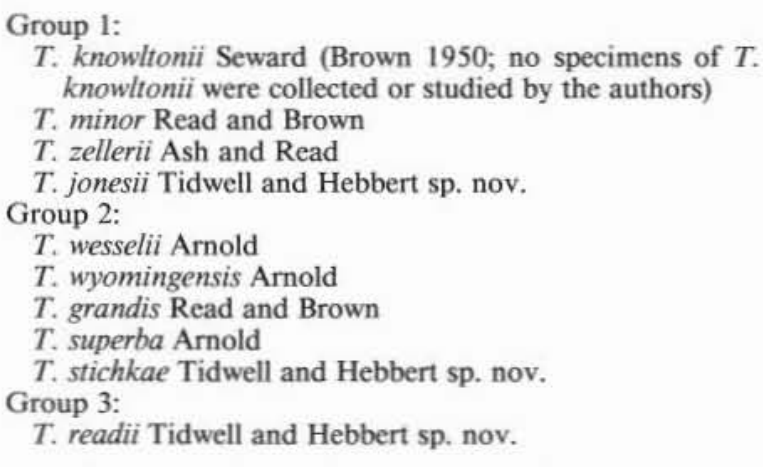

$(15.2 \mathrm{~m})$ below the top of the formation from which several Tempskya false trunks were collected in growth position (Cross et al. 1975). Pyrite occurs in the carbonaceous shales containing the bases of these tempskyas. One specimen also extended through a sandstone lens (Tidwell and Hebbert 1976; Tidwell et al. 1976). Specimens of the angiospermous wood Paraphyllanthaxylon utahense and fronds of the fern Frenelopsis variens were collected from a nearby site in association with weathered specimens of Tempskya (Thayn et al. 1983). Fronds of Anemia fremontii were also found as compressions imbedded in the coalified sediments around the in situ false trunks. The 500 specimens of Tempskya from this locality are represented by $T$. minor, $T$. stichkae sp. nov., $T$. jonesii sp. nov., and $T$. wesselii.

LOCALITY 2. The Ferron locality is $15 \mathrm{~km}$ east of Ferron, Utah (site 2 in Thayn et al. 1983; NE $1 / 4$, $\mathrm{SW}^{1} \frac{1}{4}$, Sec. 23, T20S, R8E). At this site, the Cedar Mountain Formation consists of coarse, white sandstone overlain by channel fills of yellow conglomeratic sandstone alternating gray-green shales and underlain by a dark-green, nodular weathering shale. Five specimens of $T$. jonesii occur at this locality in association with cycadeoids, the coniferous woods Mesembrioxylon stokesii (Thayn and Tidwell 1984) and Palaeopiceoxylon thinosus (Tidwell and Thayn 1985), and the angiospermous woods Paraphyllanthoxylon utahense and Icacinoxylon pittiense (Thayn et al. 1983, 1985).

LOCALITY 3. This locality is ca. $3.2 \mathrm{~km}$ south of locality 2 in SW11/4, Sec. 26, T20S, R8E. Tempskya occurs above a thin coalified seam approximately $2.5 \mathrm{~cm}$ thick in the Cedar Mountain Formation and over $3.2 \mathrm{~m}$ long containing "platanoid" flowers, petrified angiospermous woods, two or three types of ornithischian teeth, several teeth belonging to crocodilians and fish, at least two different types of dinosaur egg shells (Tidwell et al. 1983), lizard teeth, turtle carapace frag- ments, and several mammal teeth (Nelson and Crooks 1987).

Locality 4. Cedar Mountain Formation in the Yellowcat area south of Interstate Highway 70 and west of the Westwater locality (Sec. 9, T245, R205). Tempskya jonesii was identified from this area.

LOCALITY 5. Westwater locality occurs at the same site as the flora reported from the Dakota Formation by Rushforth $\left(1970,1971 ;\right.$ NW$^{1} / 4$, Sec. 17, T19S, R26E). Thirteen specimens of Tempskya have been collected in this formation from the lower sandstone bed, the lower coal bed, and within the ash bed containing the leaf compressions Matonidium and Gleichenia. Tempskya jonesii, $T$. minor, and possibly $T$. knowltonii (Brown 1950) occur at or near this locality.

LOCALITY 6. Moab airport locality is situated in the low hills ca. $1.6 \mathrm{~km}$ directly southeast of the Moab airport (Sec. 10, T24S, R20E). Here tempskyas occur horizontally and are oriented in a northwest-southeast direction in the Cedar Mountain Formation, although some authors (McKnight and Rigby 1963; Ash and Read 1976) assigned this unit to the Burro Canyon. McKnight and Rigby (1963) noted numerous fragmented sections of Tempskya at this locality, some up to $1.5 \mathrm{~m}$ long in an argillaceous siltstone and sandy shale interbedded with pebble conglomerate. The in situ specimens were surrounded by a dark gray to black peatlike material which probably represents the remains of a mat of Tempskya roots. Most of the pieces and the more complete false trunks appeared to have been abraded or partially decomposed prior to burial. This locality contained 56 specimens assigned to $T$. stichkae, $T$. wesselii (fig. 24), T. wyomingense (figs. 22, 23), $T$. grandis (fig. 31), and $T$. jonesii.

Locality 7. The Blue Mesa site is southeast of Moab, Utah (NE $1 / 4$, Sec. 16, T28S, R23E), in the upper portion of the Burro Canyon Formation. At this locality, abundant specimens (614) of Tempskya occur in a bed of thick, black carbonaceous shale on top of a cliff composed of light $\tan$ to brown massive sandstone. Species from the Blue Mesa locality include $T$. minor, $T$. jonesii, $T$. readii, $T$. superba, and $T$. zellerii. Some of the specimens from the Blue Mesa locality, although badly fractured, have been collected nearly intact from this site. One was over $1.8 \mathrm{~m}$ long. A specimen of Icacinoxylon pittiense, without growth rings, was associated with these tempskyas.

LOCALITY 8 . This is possibly the Dakota Formation in the La Sal Mountains which Read and Brown (1937) described as "on the divide southwest of Winburn's Ranch, near the head and on the northwest side of Pack Creek, just west of Mount Peale" (p. 127; possibly Sec. 27, T27S, R24E). Read also collected Tempskya ca. $24 \mathrm{~km}$ 

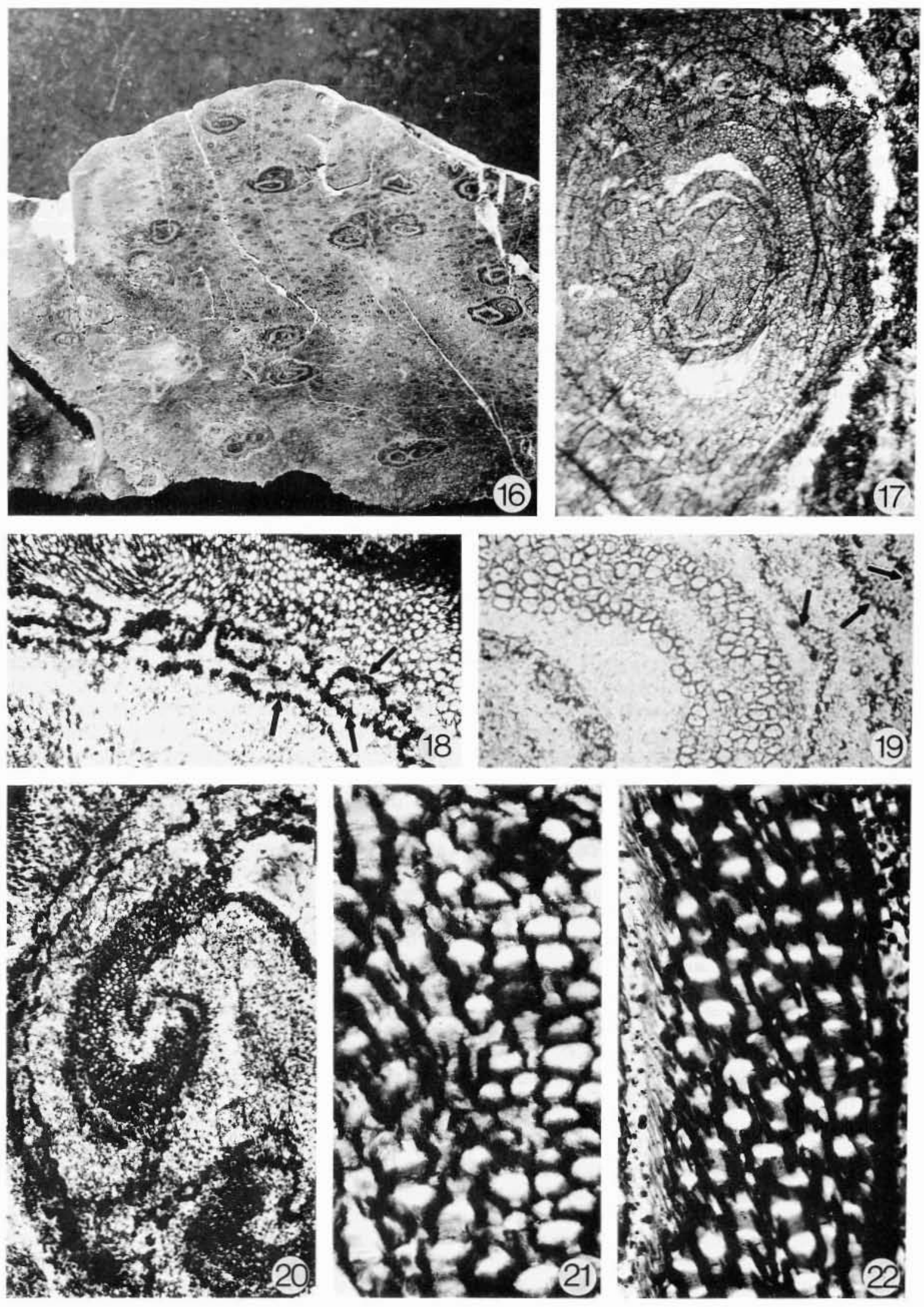

cortex fusing to two when connecting with those in the trace. Specimen 5048 ( $\times 30$ ). Fig. 21, oblique view of the xylem of $T$. stichkae showing scalariform walls. Specimen 5048 ( $\times 90)$. Fig. 22, Oblique view of the xylem of $T$. wyomingense illustrating the scalariform walls of the tracheids. Note the absence of parenchyma. Specimen 5049 ( $\times 90)$. All transverse sections. 
south of this area (Ash and Read 1976). They did not identify the species.

LoCALITY 9. On Cottonwood Creek ca. $8 \mathrm{~km}$ southwest of Blanding, Utah (SE1/4, Sec. 24, T37S, $\mathrm{R} 21 \mathrm{E})$. Although the shale in which the tempskyas occur is assigned to the Burro Canyon Formation, the strata more closely resemble the Cedar Mountain Formation. The only species observed by the authors from this locality is $T$. minor.

\section{Systematics (figs. 2-40, table 2)}

FAMILY. Tempskyaceae

Genus. Tempskya Corda

SPECIES. Tempskya Jonesii sp. nov. (figs. 2-12)

Diagnosis. False trunk, upward of $30 \mathrm{~cm}$ in diameter, radially symmetrical; individual stems dorsiventral, 2-ranked, 4-4.5 $\mathrm{mm}$ in diameter; dichotomizing; solenostelic; internodes very long, $11 \mathrm{~mm}$, generally showing one, rarely two, leaf traces in cross section; outer cortex 3-4 cells wide transversely, contains tangentially elongated parenchyma cells; middle cortex $12-15$ cells across, homogeneous, sclerenchymatous, 12-15 cells across; inner cortex $6-12$ cells in width, parenchymatous, filled with dark contents; xylem without parenchyma; pith consisting of two zones, outer zone parenchymatous, inner zone sclerenchymatous.

REPOSITORY. BYU 5046 (holotype), 5045, 5051 (paratypes).

\section{LOCALITY. 1-7.}

AgE. Late Early Cretaceous (Albian) and early Late Cretaceous (Cenomanian).

Horizon. Cedar Mountain, Burro Canyon, and Dakota Formations.

Etymology. The specific name honors Stanley Jones of Castle Dale, Utah, for showing us the Castle Dale locality.

\section{Description}

False trunks of this species vary from round to flattened (fig. 2). The latter shape, however, results largely from uneven weathering. The holotype contains upward of 270 stems in a cross section near the base of the false trunk. The stems are solenostelic, dorsiventral, and radially oriented in the false trunk (figs. 3,6). The dichotomously branched stems are sheathed in adventitious roots which generally parallel the stems (fig. 5) and, in some specimens, invade the stems in the older portions of the false trunks.

The epidermis is composed of tangentially elongated cells which have masses of very long epidermal hairs extending from them. A cuticle, $3 \mu \mathrm{m}$ thick, covers the epidermis.

The cortex consists of three parts (figs. 7, 8). The outer cortex consists of large, tangentially elongated parenchyma cells. Transversely, this tissue is $3-4$ cells wide.

Homogeneous sclerenchymatous tissue forms the middle cortex, and the inner cortex is composed of only parenchyma cells (figs. 9, 10). The latter tissue is $12-14$ cells wide. Its cells are generally filled with dark contents. Because of its parenchymatous nature, the inner cortex is often not or only partially preserved in many specimens.

The endodermis, although poorly preserved, appears as a single layer of dark cells on each side of the xylem strand and ensheathes the pericycle, phloem, and xylem sheath. The pericycle appears to be upward of two cells thick and the phloem varies from one to three cells in width.

The xylem is 10 (rarely 13) cells thick and consists only of angular, sometimes flattened and distorted, scalariform tracheids (fig. 12). The protoxylem is exarch and composed of small tracheids with spiral thickenings. A two-zoned pith with parenchyma cells next to the inner endodermis and sclerenchyma constituting the middle portion is enclosed within the vascular strand of the stem.

Leaf traces arise in two ranks from the stem. Their place of origin is marked by a thinning of the stele. The xylem is $3-6$ tracheids wide at this point. In transverse section, the leaf trace begins as an outward bulging of the vascular tissues of the stem which forms the beginning of a gap. The parenchyma and sclerenchyma of the pith also bulge outward and fill the center of the gap. As the gap expands outward, it expands tangentially as well, becoming somewhat pear shaped. The leaf trace separates from the stele first on one side and at a higher level on the other. The three zones of cortical tissue encircle the leaf trace as it passes outward; and parenchyma and sclerenchyma of the pith occupy the adaxial curvature of the trace.

Figs. 16-22 Fig. 16, False trunk of Tempskya stichkae sp. nov, in transverse section. Specimen 5048 (× 1). Fig. 17, Stem with departing leaf trace in false trunk of fig. $16(\times 10)$. Fig. 18, Enlargement of outer pith of a stem of T. stichkae showing the three bands of sclerenchyma (arrows) with the two outermost fusing together in certain areas. Specimen 5048, 1 ( $\times 30$ ). Fig. 19, Enlargement of the inner cortex of $T$. stichkae illustrating the three bands of sclerenchyma (arrows) in this tissue. Specimen 5048, I ( $\times 20)$. Fig. 20, Leaf trace of $T$. stichkae departing from stem. Note the three sclerenchyma bands of inner 

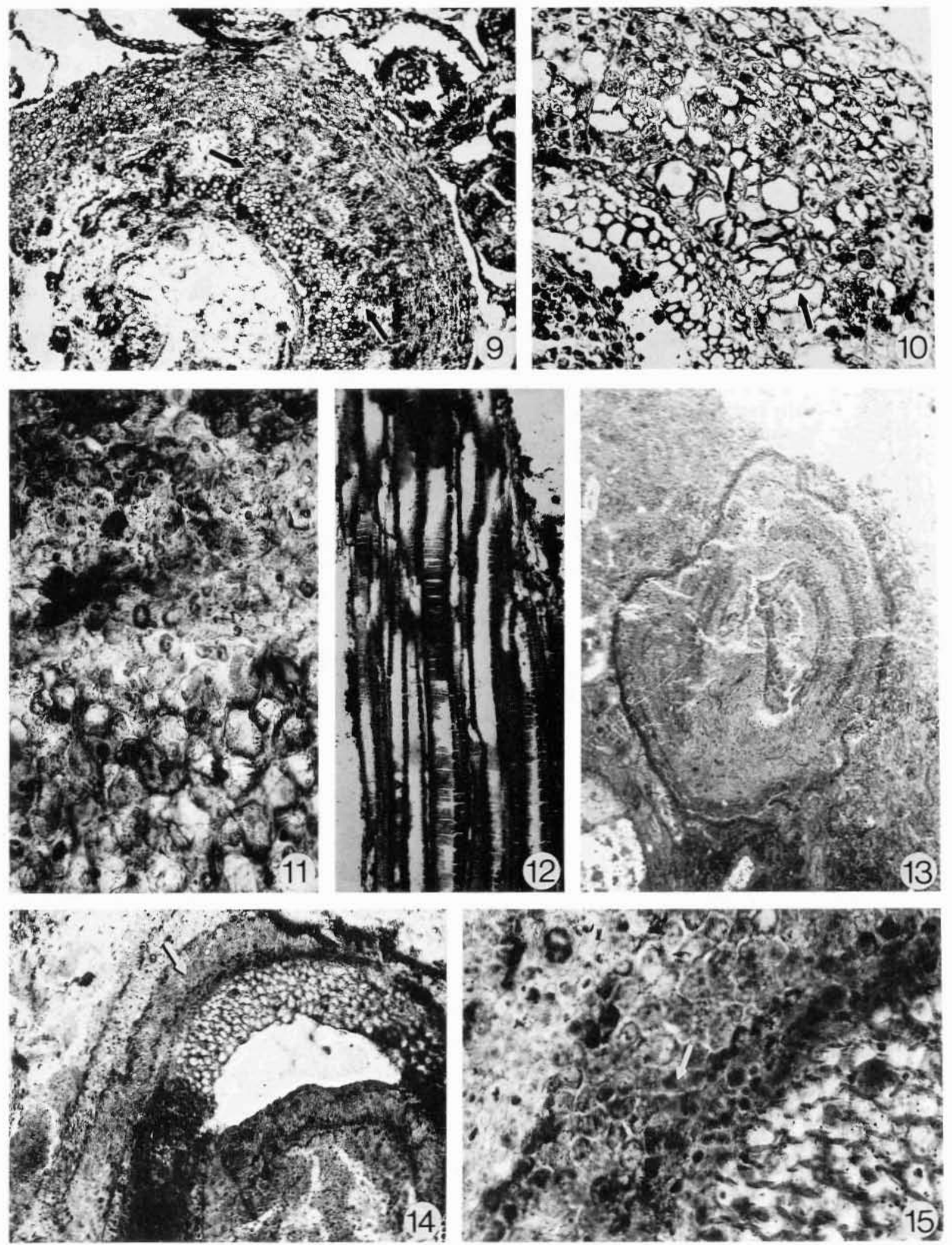

Figs. 9-15 Figs. 9, 10, 11, Parenchymatous inner cortex (arrows) in transverse sections of a portion of a stem of Tempskya jonesii. Specimen $5046(9, \times 25 ; 10, \times 75 ; 11, \times 90)$. Fig. 12, Longitudinal view of metaxylem elements of the xylem of a stem of $T$. jonesii. Specimen 5046 ( $\times 90)$. Fig. 13, Cross section of a stem of $T$. readii. Specimen 5047 ( $\times 8$ ). Fig. 14, Closeup of a stem of $T$. readii in transverse section showing the sclerenchymatous inner cortex (arrows). Specimen 5047 ( $\times 15$ ). Fig. 15, Enlargement of the inner cortex of a stem of $T$. readii illustrating the sclerenchyma (arrows) in the inner cortex. Specimen $5047(\times 90)$. 
The C-shaped trace enters the petiole base upon leaving the stem. The xylem strand in both the leaf traces and petiolar vascular strands is thin in the middle (1-3 tracheids in width) and thickened laterally. The petioles are short and often are invaded by roots. Adventitious roots arise from the stele opposite the leaf traces.

\section{Comparison}

The lack of parenchyma in the xylem and sclerenchyma in the outer pith and inner cortex in Tempskya jonesii is similar in $T$. minor and $T$. knowltonii. However, longer internodes and a radial arrangement of the stems in the false trunk of $T$. jonesii distinguish it from these species.

SPECIES. Tempskya stichkae sp. nov. (figs. 16-21)

Diagnosis. False trunk, over $17 \mathrm{~cm}$ in diameter, radially symmetrical; stems dorsiventral, solenostelic, $6-8 \mathrm{~mm}$ in diameter; leaves 2-ranked; internodes intermediate, 5-7 mm long with $1-2$, rarely 3 , leaf traces present in cross section; epidermal cells filled with dark contents with epidermal hairs attached; outer cortex thin, 4-5 thick-walled cells wide; middle cortex homogeneous, sclerenchymatous, $20-25$ cells wide; inner cortex parenchymatous with 3 thin, discontinuous zones of sclerenchyma more or less evenly spaced and occasionally connected; xylem parenchyma absent; pith, having a sclerotic center, parenchymatous near inner endodermis, containing three zones of sclerenchyma similar to that of inner cortex.

\section{REPOSITORY. BYU 5048 (holotype).}

LOCALITY. 1,6 .

AgE. Late Early Cretaceous (Albian).

Horizon. Cedar Mountain and Burro Canyon Formations.

Etymology. The specific epithet honors James Stichka of Walnut Creek, California, for his continued scientific interest in Tempskya.

\section{Description}

Known false trunks of this species are incomplete (fig. 16). The holotype is $18 \mathrm{~cm}$ across with radially oriented dichotomously branching stems.

A poorly preserved epidermis with numerous attached epidermal hairs and three zones of cortical tissue form the outer portion of the stem. Cells of the epidermal hairs are $50 \mu \mathrm{m}$ wide and $150 \mu \mathrm{m}$ long near their bases. The hairs are very long and also occur on the petioles and roots. Cells of the thin outer cortex are 50-60 $\mu \mathrm{m}$ across and filled with dark contents. The middle cortex consists of homogeneous, sclerenchymatous tissue of cells with small lumens filled with dark contents and thick walls which are often not preserved. Parenchymatous tissue containing three thin (1-3 cells wide), more or less continuous zones of sclerenchyma constitutes the inner cortex (fig. 19). Generally, the sclerotic zones are separate from one another, but occasionally strands of sclerenchyma connect the innermost and middle zone together. The inner zone is 79 cells wide, and the outer zone is $8-10$ cells thick.

Although generally poorly preserved, the Casparian strips are seen on some cells of the singlelayered endodermis, and a single-layered pericycle has cells $25 \mu \mathrm{m}$ in diameter. Phloem, where preserved, appears as patches $1-3$ cells wide. The xylem sheath is not preserved.

Angular, sometimes distorted, scalariform tracheids without parenchyma compose the xylem strand (fig. 21). No definite protoxylem could be identified.

The pith consists of a sclerotic center and parenchymatous outer layers, with three zones of sclerenchyma similar to those in the inner cortex occurring next to the inner endodermis (fig. 18).

Leaf traces arise in two ranks from the stem and develop essentially in the same manner as those in Tempskya jonesii. The three zones of the inner cortex continue around the outside of the leaf trace, but where they connect with the three zones of sclerenchyma from the pith, the middle and outer zones fuse, resulting in only two zones of this tissue lining the adaxial concavity of the leaf trace and petiolar vascular strand (fig. 20). Petioles in this species extend $20 \mathrm{~mm}$ from their stems before they are destroyed by roots. Roots originate from the stele opposite the leaf traces.

\section{Comparison}

Specimens of Tempskya stichkae appear to be similar to $T$. superba in general internal structure, although they differ in stem size. The stems are 6-8 $\mathrm{mm}$ in diameter, but the departing leaf traces cause them to appear much larger. The outer pith and inner cortical layers in the holotype of this new species are well preserved and contain three irregular strands of sclerenchyma, rather than one irregular band as in T. superba (Arnold 1958), or two as in $T$, wyomingense (Arnold 1945). In general, it is unlike any other species of Tempskya.

\section{SPECIES. Tempskya readii $\mathrm{sp}$. nov.} (figs. 13-15)

Diagnosis. False trunk, radially symmetrical; stems dorsiventral, solenostelic, 5-7 $\mathrm{mm}$ in diameter; leaf traces 2-ranked; internodes intermediate in length, 1-2 leaf traces, occasionally 3 , present in cross section; outer cortex 6-8 cells wide; middle cortex homogeneous, sclerenchy- 
matous, 11-13 cells wide; inner cortex completely sclerenchymatous; xylem parenchyma lacking; pith sclerotic both middle and near inner endodermis.

\section{REPOSITORY. BYU 5047 (holotype).}

\section{LOCALITY. 7.}

\section{Age. Late Early Cretaceous.}

\section{Horizon. Burro Canyon Formation.}

Etymology. The specific epithet honors Charles B. Read, who contributed so much to our understanding of the unique fern Tempskya.

\section{Description}

Only one small specimen of Tempskya readii was collected. Anatomically, the stems and leaf traces of this species are similar to those of $T$. stichkae. Although the pith of $T$. readii is sclerotic, the middle and outer zones of this tissue can be distinguished from one another. The sclerenchyma of the inner cortex is thick walled with medium-sized lumens (figs. 14, 15).

\section{Comparison}

Tempskya readii is distinguished from other species of Tempskya in having an inner cortex composed only of sclerenchyma and not parenchymatous as in $T$. knowltonii, $T$. minor, and $T$. jonesii, or a mixture of parenchyma and sclerenchyma as in the other species.

\section{Leaves and annuli}

Transverse sections of leaves are present in a specimen of Tempskya wyomingense (figs. 25, 26, 27). Because they are incomplete, their total length could not be determined. The lamina of these leaves is very thin. The leaves have a single-layered upper epidermis, composed of cells $7-10 \mu \mathrm{m}$ wide $\times 15-20 \mu \mathrm{m}$ long with an outer covering of cuticle $2 \mu \mathrm{m}$ thick. Elongated palisade cells, 5 $\mu \mathrm{m}$ wide $\times 12-17 \mu \mathrm{m}$ long, occur below the epidermis, and a spongy mesophyll 3-4 cells wide is present between the crushed lower epidermis and the palisade layer. Cells of the mesophyll are elongated perpendicular to the palisade cells and are 7-10 $\mu \mathrm{m}$ wide $\times 10-16 \mu \mathrm{m}$ long. The lower epidermis, although crushed, seems to have been similar to the upper. No stomata were preserved. Lateral veins, $25 \mu \mathrm{m}$ across, are spaced $43 \mu \mathrm{m}$ apart. No definite midvein was observed.

Annuli representing the remains of sporangia are observed in a specimen of $T$. wyomingense and are affixed to a receptacle which in turn is attached to the lower surface of a leaf (fig. 28). The receptacle has a broad base, $85 \mu \mathrm{m}$ across, and tapers distally $200 \mu \mathrm{m}$ to a somewhat flat- tened apex. The annuli are extended outward from a short stalk to which they are connected. The stalks are 50-60 $\mu \mathrm{m}$ wide $\times 70 \mu \mathrm{m}$ long, and the annuli are $655 \mu \mathrm{m}$ long by $16 \mu \mathrm{m}$ wide. They consist of cells $4-6 \mu \mathrm{m}$ across with cell walls varying from 1 to $4 \mu \mathrm{m}$ in thickness. The annuli appear to be of the vertical type. No spores are present.

A detached annulus present among the roots in a false trunk of $T$. wesselii (fig. 38 ) is very similar to those reported in this species from Wayan, Idaho (Andrews and Kern 1947).

\section{Animal activity}

Numerous small, reniform bodies of three sizes occur in tunnels excavated into the cortical regions of some stems, petioles, and roots, and in the masses of epidermal hairs associated with these structures in nearly all of the specimens of Tempskya examined during this study. The tunnels are circular to oval in outline and weave throughout these tissues (figs. 33, 34). Some roots consist of only a cavity filled with these bodies surrounded by the remains of the outer cortices and epidermis rather than a tunnel or gallery. The root has been essentially destroyed. These bodies represent fecal pellets similar to those previously described by Seward $(1923,1924)$. In a specimen of $T$. wyomingense most of the hair is gone and fecal pellets occur throughout the specimen. Generally, the pellets are loosely packed, nearly filling the galleries or tunnels, and seem to have been deposited by the animals as they were feeding upon the parenchyma and hairs of the stems, petioles, and/or roots. Three sizes of pellets are present, suggesting that more than one type of animal was feeding upon these plant structures. The smallest pellets $(25 \mu \mathrm{m} \times 15 \mu \mathrm{m})$ occupy round, regularly shaped tunnels. Medium size pellets $(60 \mu \mathrm{m} \times 36 \mu \mathrm{m})$ occur most commonly in elongated, irregularly shaped galleries within the epidermal hairs, and the larger ones (72-88 $\mu \mathrm{m} \times 48 \mu \mathrm{m})$ are most often found scattered between the plant tissues throughout the false trunks, although they are occasionally found in tunnels.

Fecal pellets replaced the xylem in the roots of Tempskya as reported by Seward $(1923,1924)$. Only a few xylem cells are gone from the roots containing the fecal pellets in our specimens. As indicated by frass found in fossil plants of Pennsylvanian age, herbivores appear to have been selective for cells having secondary walls such as the xylem of Premnoxylon (Cichan and Taylor 1982), or softer tissues such as the cortex of Psaronius (Rothwell and Scott 1983). The animals that produced these pellets in most of the tempskyas appear to have had an appetite for the softer tissues of the stems rather than for xylem or sclerenchyma. They seem to have had trouble pen- 

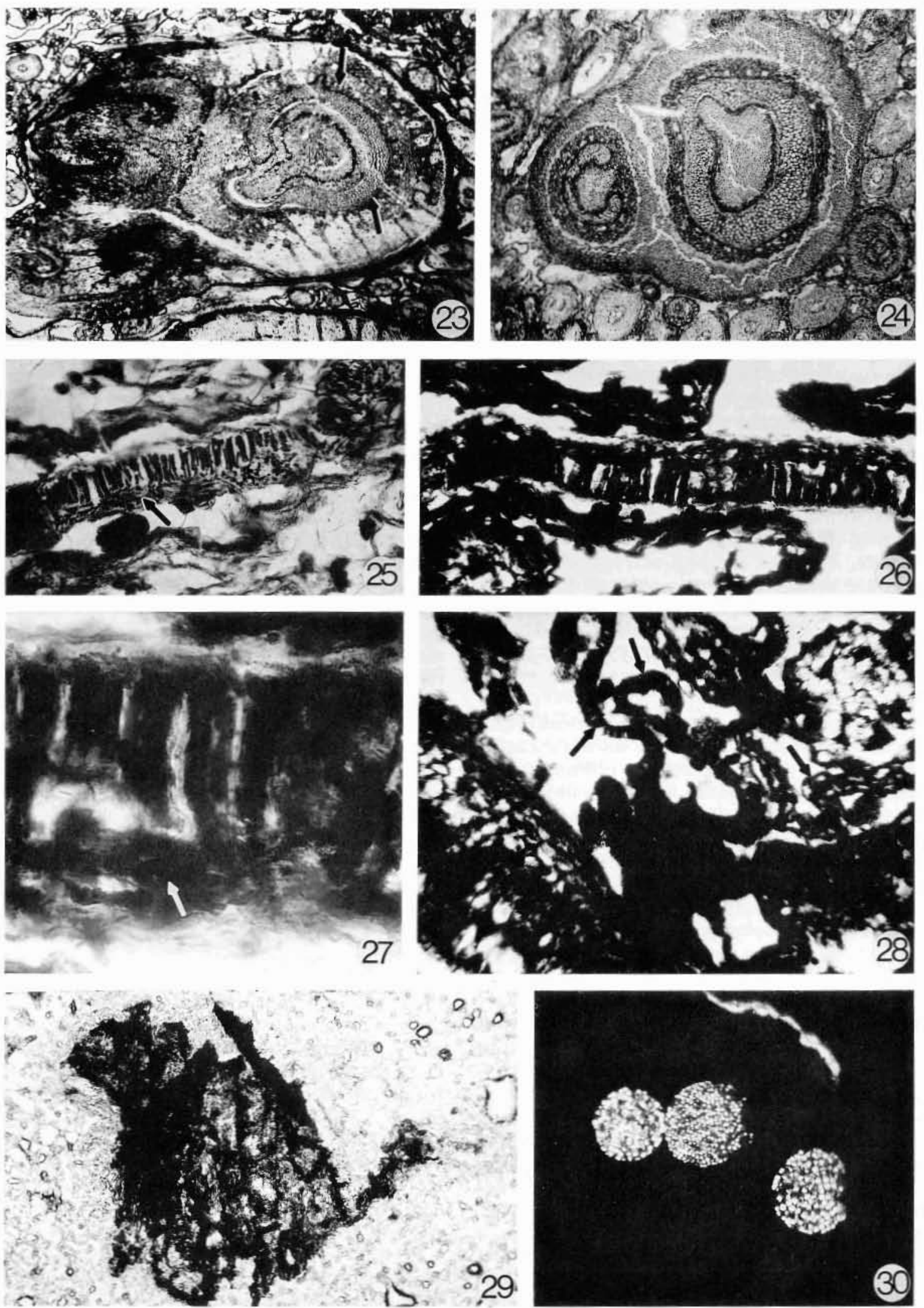

Figs. 23-30 Fig. 23, Transverse section of a stem of Tempskya wyomingense. Note the sclerenchyma (arrows) in its inner cortex. Specimen $5049(\times 8)$. Fig. 24, Cross section of a stem of $T$. wesselii with departing leaf traces. Specimen $5050(\times 15)$. Figs. 25-27, Transverse sections of leaves in T. wyomingense. The palisade layer is prominent, whereas the mesophyll has been crushed (arrow). Specimen $5049(25, \times 30 ; 26, \times 60 ; 27, \times 240)$. Fig. 28, Section through a sorus that is sessile on a leaf with the annuli (arrows) of several sporangia still attached. Specimen $5049(\times 240)$. Fig. 29, A portion of cuticle that remained after macerating a stem of $T$. jonesii. Specimen 5051 ( $\times 150)$. Fig. 30, Framboidal pyrite, macerated from carbonaceous shale $(\times 400)$. 

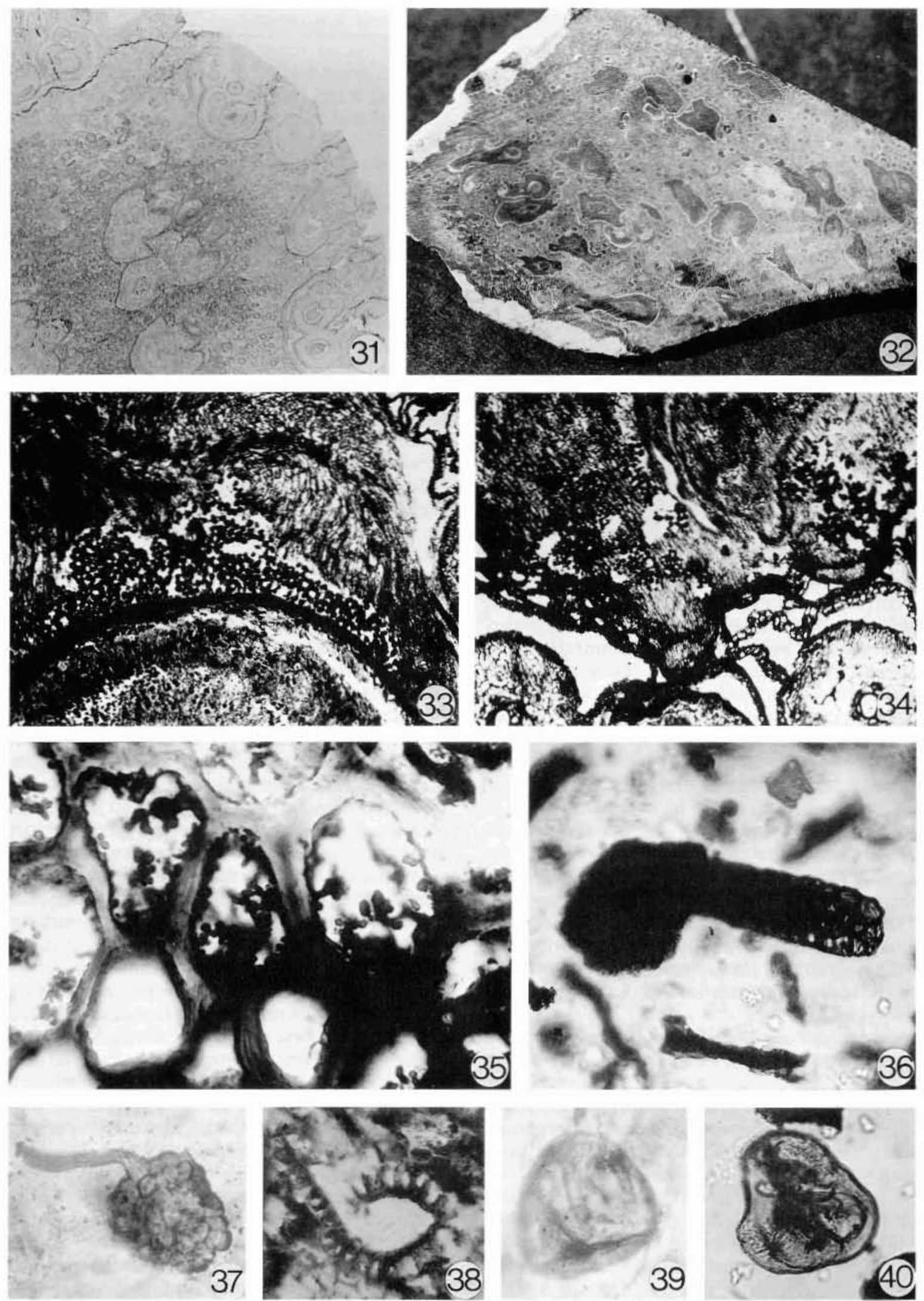

Figs. 31-40 Fig. 31, Transverse section of Tempskya grandis. Specimen $5052(\times 1.5)$. Fig. 32, Cross section of $T$. zellerii. Specimen $5053(\times 2)$. Figs. 33, 34, Fecal pellets in tunnels in the epidermal hairs of two stems of $T$. wyomingense. Specimen $5049(\times 25)$. Fig. 35, Arbuscules of V-A mycorrhizal fungi in cells in a root of $T$. wyomingense. Specimen $5049(\times 250)$. Figs. 36, 37, Unidentified germinating fungal spores from maceration of false trunk of $T$. jonesii. Specimen 5051 ( $\times 400$ ). Fig. 38, Annulus of a sporangium in $T$. wesselii. Specimen $5050(\times 25)$. Figs. 39, 40, Spores from the maceration of a portion of a false trunk of $T$. jonesii. Specimen 5051 ( $\times 350)$. 
etrating the harder tissues as evidenced by the general absence of fecal pellets in the pith of the stems, unless the stems were first split apart by invading roots. Designation of any particular animal to these pellets is problematical because different animals in diverse groups produce the same or similar pellets (Häntzschel et al. 1968).

\section{Fungal activity}

Hyphae resembling the dichotomous branching or arbuscules of vesicular-arbuscular (V-A) mycorrhizal fungi occur in the cortices of some roots in these false stems, particularly Tempskya jonesii (fig. 35). The branches appear to become progressively smaller in size with each level of branching. The genus to which they can be assigned is problematical, but living forms are known to occur in thalli, rhizomes, or roots of ferns (Bonefante-Fasolo 1984). Several forms of living V-A mycorrhizas may also infect the same plant. All living members are placed in the family Endogonaceae of the order Mycorales in the class Zygomycetes (Hall 1984). In living forms, these mycorrhizas represent an extreme form of adaptation to a symbiotic mode of life. It is uncertain what contribution these fossil forms may have made to the Tempskya roots. They may have stimulated growth, helped in nutrient uptake, improved water transport, and possibly increased the resistance to pathogens as they do in modern roots (Jackson and Mason 1984).

Read (1983) concludes that living V-A mycorrhizas do best in areas of high mineral nitrogen availability with low polyphenol content in low latitudes and at low altitudes. Some species, however, do occur at high altitudes and in the most acid moor and bog soils. They develop the greatest in moist temperate and tropical lowlands where plants containing V-A mycorrhizal are dominant in the vegetation (Harley and Smith 1983). This may have been the case in their association with Tempskya as well.

Numerous fungal spores are also present in the maceration residue of a false trunk of $T$. jonesii (figs. 36, 37). It is uncertain whether any of these spores were produced by the V-A mycorrhizal fungi. No hyphae are associated with the spores.

\section{Discussion}

Twelve species of Tempskya have been described from North America, eight, possibly 10, from Europe, most of which are imperfectly known, and one from Japan. The latter species (T. iwatensis) was reported from Upper Cretaceous strata (Nishida 1986) rather than being of Early to mid-Cretaceous age as were the others (Ash and Read 1976).

Characters delimiting the species in Tempskya (table 2 ) have been reviewed by Read and Brown
(1937), Arnold (1945, 1958), Chandler (1968), Ash and Read (1976), and Nishida (1986). Perhaps the basic criterion is whether a species has radial or dorsiventral symmetry (Seward 1924). Although the idea of dorsiventrality has been viewed with skepticism by some (Andrews and Kern 1947), others have deemed it to be valid (Read and Brown 1937; Ash and Read 1976; Nishida 1986). Tempskya jonesii is very similar to $T$. knowltonii, and the major difference between the two is that the symmetry for $T$. jonesii is radial, whereas that of $T$. knowltonii is dorsiventral. The specimens of $T$. minor included in this study appear more radial than dorsiventral; otherwise they are anatomically similar to the type. Dorsiventral trunks were postulated to have grown along the ground and then eventually to have grown upright (Seward 1924). Read (1939) thought perhaps they grew as lianas or vines leaning against rock outcrops of steep cliffs or climbing on arborescent plants. We did not see any indication of this occurring, and in our opinion, it never did. Among tree ferns, there are species illustrating these different growth patterns. $\mathrm{Ci}$ botium barometz, for example, has a creeping habit of its stem which differs from the upright species of the genus (Ogura 1927). However, unlike $T$. knowltonii, the stele of $C$. barometz retains its radial symmetry.

The arrangement of the tissues in the pith and cortices of the stems, particularly in the inner cortex, is considered to have systematic value (Read and Brown 1937; Arnold 1945, 1958). Ash and Read (1976) subdivided the western North American species into two broad groups based upon the character of this tissue: one group was characterized by a simple three-layered type of cortex with an inner parenchymatous cortex, and the other included species with mixed tissues of parenchyma and sclerenchyma in their inner cortices. Like Ash and Read (1976), we consider this to be a valid character, and $T$. jonesii is hereby placed in the first group and $T$. stichkae in the second. However, the inner cortex and the outer zone of the pith of $T$. readii are completely sclerotic in its stems. The completely sclerotic inner cortex of $T$. readii does not allow this species to be assigned to the other two groups. Therefore, a third group containing only sclerenchyma in its inner cortices is proposed for $T$. readii.

The center of the pith is sclerotic in all species, except $T$. reesidei, which has a parenchymatous center, and $T$. readii, which has a completely sclerotic pith. In general, the outer zone of the pith is similar to the inner cortex as to the disposition of sclerenchyma and parenchyma in that particular species of Tempskya. Tempskya wesselii and $T$. wyomingense, however, differ in lacking sclerenchyma in the outer layer of their piths at the same time they have sclerenchyma in their inner 
cortices. This difference is also a valid specific character.

Stem diameter has been used to a limited extent for specific separation (Arnold 1958), but Chandler (1968) considered stem size alone not to be sufficient reason for separation, and, in general, this may be true. She stated that stems varied considerably in size in her specimen depending upon their position within the false trunk. We have studied many nearly intact specimens and have found very little variation in stem size from the bases of the false trunks to near their apices. In other words, if they are large, such as those in $T$. superba, they remain large, and if they are small, such as those in $T$. jonesii, they stay small.

The correlation between stem diameter and internodal length used as a specific character by Read and Brown (1937) has been largely discounted (Ash and Read 1976). The internodal length itself is valid as a specific character. The relative length of the internodes in Tempskya has been derived by using the number of visible leaf traces in a cross section. However, if the length of the internodes were determined by actual measurement of longitudinal sections of the stem, the results would likely be more accurate.

Using the amount of parenchyma in the xylem to distinguish species of Tempskya has been questioned (Arnold 1958; Ash and Read 1976). Among conifers, the presence of parenchyma in the xylem are actually the tips of overlapping tracheids.

The systemic value of the persistence of petioles in the false trunks away from the stems is questionable. Petioles are destroyed by roots and, therefore, their number would vary as to their position in the false trunk. They are generally invaded by roots in older portions of the trunk and appear to have ceased functioning at the time of root invasion.

Roots are essentially the same in all species of Tempskya and therefore of no definite taxonomic value. In some species, such as $T$. stichkae, there are small differences. The proportion of larger roots to smaller ones is lower in this species than in the others where roots are closer to being the same size. The roots of $T$. zellerii also have a tendency to become distorted and angular, which does not occur in the other species. Roots of all species, except $T$. zellerii, encountered in this study have an abundance of attached epidermal hairs as noted by Nishida (1986). These hairs are essentially the same as those produced by the epidermis of the stem and, in the case of $T$. stich$k a e$, the petioles. Epidermal hairs are not present on the petioles in the other species. The epidermal hairs in $T$. stichkae are wider at their bases than those of other species.

The false trunks of $T$. minor do not contain many stems, and most of those observed have been invaded by roots. These invaded stems have ruptured, and it is possible to observe only the outer portion of the ruptured stem, portions of the pith, leaf traces, and other internal structures of the stem. Invaded stems which have not ruptured are expanded until they are much larger than normal, and the major portion of the internal structure has been replaced by roots. The arrangement of the stems within the false trunks in the Utah specimens of $T$. minor also appeared to be more radial than dorsiventral.

A variety of fungal (figs. 36, 37) and fern spore types have been observed in the macerated material from the false trunks of $T$. jonesii. Most of the fern spores (figs. 39,40 ) are similar to those illustrated by Andrews and Kern (1947, text fig. 8 ), and although not conclusive, the number of these spores present suggests they are most likely the spores produced by Tempskya. These spores, however, differ from those described by Boodle (1895) from a specimen of $T$. schimperii collected on the Isle of Wight. The spores from the Utah specimens are smooth walled rather than being conspicuously sculptured with long bars as are those from $T$. schimperii.

Tempskyas collected in growth position at the Castle Dale locality (locality 1) were separated from each other by ca. $1.2 \mathrm{~m}$ and were either truncated or tapered to a flattened top. None had preserved apices. These specimens were embedded in undisturbed carbonaceous shale containing pyritic sulphur, which implies that they inhabited a reducing, swampy environment similar to some of those in the Mississippi River Delta or the Florida Everglades. The abundant sulphur minerals in these carbonaceous shales occur mostly in the form of framboidal pyrite which is formed in sulfuritic environments during early diagenesis. Although marine peats have higher sulphur content than freshwater peats (Casagrande 1987), pyrite is most abundant in peats formed under brackish water environments (Cohen et al. 1987). Other abundant minerals in these sediments include limonite, clay, and carbonate. Vitrinite macerals in these shales are generally pitted and occur along with fusinites. Pyrofusinites, with higher reflectance, are frequently encountered in the coalified material in these carbonaceous shales and probably resulted from charring of peat swamp vegetation during occasional surface fires (Stach et al. 1982, pp. 272274). It is unclear whether such fires also affected a forested area near the site of deposition of these tree ferns (Nambudiri, personal communication 1987).

Based upon the abundance of Tempskya specimens and their wide geographic distribution in Utah and adjacent states, these swamps must have been fairly common during the time of deposition of the Cedar Mountain and Burro Canyon Formations and other formations of equivalent age. 
Table 2

KeY to TeMPSkyA SPECIES

1. Individual stems of false trunk medium to large (5-15 $\mathrm{mm}$ ) in diameter. Inner parenchymatous layer of the cortex containing continuous and/or discontinuous bands of sclerenchyma. False trunks have radial symmetry.

A. Inner parenchymatous layer of cortex and exterior of pith contain a single discontinuous and irregular band of sclerenchyma. Internodes short to medium permitting overlapping (2-5) of leaf bases.

1. Individual stems medium, 4-6 mm in diameter. Tempskya grandis

2. Individual stems large, $10-15 \mathrm{~mm}$ in diameter. Tempskya superba

B. Inner parenchymatous layer of cortex contains two bands of sclerenchyma, separated by a continuous or discontinuous band of parenchyma. Outer band of sclerenchyma is continuous, and the inner band may be either continuous or discontinuous. Exterior of pith does not contain a band of sclerenchyma. Internodes medium to long, permitting very slight to slight overlapping $(1-3)$ of leaf bases.

1. The two bands of sclerenchyma in the inner parenchymatous layer of cortex connected locally by strands of sclerenchyma, giving an impression of "islands" of parenchyma surrounded by sclerenchyma. Internodes medium in length, permitting slight overlapping (2-3) of leaf bases. Pith parenchymatous. Tempskya reesidei

2. The two bands of sclerenchyma in the inner parenchymatous layer of cortex completely separated from each other by a continuous band of parenchyma. Outer pith lacks sclerenchyma.

a) Internodes long, permitting very slight overlapping (1-2) of leaf bases. Individual stems 4-5 $\mathrm{mm}$ in diameter. Tempskya wesselii

b) Internodes medium in length, permitting slight overlapping (2-3) of leaf bases. Individual stems $6-8 \mathrm{~mm}$ in diameter.

Tempskya wyomingensis

3. Inner parenchymatous layer of cortex and exterior of pith contains three bands of sclerenchyma separated by continuous or discontinuous bands of parenchyma. Outer band continuous and inner bands either continuous or discontinuous. Internodes medium (2-3).

Tempskya stichkae

4. Inner layer of cortex and pith completely sclerotic.

Tempskya readii

II. Individual stems of false trunk small to medium (2.5$8.0 \mathrm{~mm}$ ) in diameter. Inner parenchymatous layer of the cortex does not contain continuous or discontinuous layers of sclerenchyma. False trunks have either dorsiventral or radial symmetry.

A. Individual stems and steles angular in transverse section, approximately $3-8 \mathrm{~mm}$ in diameter. Internodes relatively long, permitting only slight overlapping (1-2) of leaf bases. Tempskya zellerii

B. Individual stems and steles round to subround in transverse section. Intemodes long, permitting slight overlapping (2-3) of leaf bases.

1. False trunks dorsiventral, sometimes approaching radial. Stems approximately $2.0-3.5 \mathrm{~mm}$ in diameter.

Tempskya minor

2. False trunks radial. Stems approximately $4-4.5$ $\mathrm{mm}$ in diameter.

Tempskya jonesii

3. False trunks dorsiventral or radially symmetrical. Stems approximately $2.5-7.0 \mathrm{~mm}$ in diameter.
Table 2 (Continued)

a) False trunk dorsiventral. Xylem exarch. Stems approximately $2.5-3.5 \mathrm{~mm}$ in diameter.

Tempskya knowltoni

b) False trunk radially symmetrical. Xylem exarch or possibly slightly immersed in some specimens. Xylem ring containing much parenchyma (?). Stems $6-7 \mathrm{~mm}$ in diameter.

Tempskya rossica

Note. In earlier reports on Tempskya (Read and Brown 1937; Ash and Read 1976) efforts were made to summarize the distinctions of the better-known species of Tempskya. Accordingly, a modified key has been prepared which includes the better-known and new species of the genus proposed in this paper (modified from Ash and Read [1976] with permission of S. R. Ash).

Tempskya associated with the coals in the Dakota Formation reinforces the concept that they grew under swampy conditions. Along with Anemia fremontii, specimens of Tempskya occur in the Cedar Mountain Formation with fossil woods of Paraphyllanthoxylon utahense and Icacinoxylon pittiense, which lack growth rings, and Mesembrioxylon stokesii with indistinct rings. Lack of rings is considered to be evidence for equable year-round temperatures and rainfall (Creber and Chaloner 1985; Crabtree 1987) in humid areas (Creber 1977). Paraphyllanthoxylon idahoense Spackman (1948) is associated with $T$. wesselii in the Lower Cretaceous Wayan Formation in southeastern Idaho. This angiospermous species also lacks growth rings. The nearest living relatives of these angiospermous woods are found in subtropical or tropical regions (Thayn et al. 1985). Conifer wood having indistinct growth rings assigned to Cupressinoxylon sp. (Andrews and Kern 1947) and leaves of Anemia fremontii and Gleichenites coloradensis have also been collected associated with Tempskya from the Wayan Formation. These leaf forms have been related to the modern genera Anemia and Gleichenia which are tropical to warm subtropical in their present distribution (Andrews and Kern 1947).

Tempskyas in the Dakota Formation grew with many different forms of angiosperms and ferns (Rushforth 1971), particularly Gleichenia and Matonidium, whose nearest living relative $\mathrm{Ma}$ tonia grows on the Malay Peninsula and Borneo (Seward 1899).

The presence of growth increments in specimens of Paleopiceoxylon thinosus, which have been collected in association with Tempskya and the fossil woods without rings at the Ferron locality, can be explained in three ways. This plant may have lived on an edaphic site with poor water supply in a tropical or subtropical region as indicated by the other plants or it may have lived in a wetland forest, marsh, or bog at a low elevation with long periods of inundation phase which will also produce growth rings (Worbes 
1989). A third possibility is that $P$. thinosus may have been transported from higher elevations where cyclic climatic conditions very likely could have occurred and reposited in a lowland area.

A habitat for Tempskya suggested by Andrews and Kern (1947) and Nishida (1986) is a humid low to high montane forest in subtropical or even warm temperate climate. Modern tree ferns require high humidity for continuous growth such as in tropical to subtropical South America, where cloud forests rich in ferns are well developed on Andean slopes (Nishida 1986). They also grow at lower elevations in climates characteristic of New Zealand, Australasia, and Malaysia. However, tempskyas from Utah appear not to have grown in montane areas but, rather, in swamps on flood plains. Since evaporites are not associated with Tempskya localities a lower evaporation rate resulting from high humidity (Parrish et al. 1982; Nishida 1986) was likely required by Tempskya. This concept strongly contrasts with the proposition that much of the Cedar Mountain Formation was semiarid, with caliche forming at the time it was being deposited (Nelson and Crooks 1987).

Seward (1924) considered that Tempskya grew either partially or completely beneath the soil in its beginning stages, later becoming erect or vertical. There was no indication that this happened in the false trunks found in growth position at the Castle Dale locality (locality 1). The sediments around these trunks were compact, and if any horizontal false trunks had occurred below the vertical ones, then there should have been some indication of their occurrence. Bases of these vertical false trunks had from three to nine lobes, with each lobe containing a stem that divided dichotomously upward. This implies the possi- bility of more than one plant being involved in the formation of each false trunk. Granting this possibility, then the potential exists for more than one species of stems being present in the same false trunk. However, there is no indication that this ever happened. It is more likely that the gametophyte of Tempskya was broad and vascularized, and that the sporeling stage gave rise to the initial stems in the false trunks. The gametophyte, being composed of thin-walled cells, would have eventually disintegrated and added nutrients to the trunks. Since the roots of Tempskya appear to have invaded almost everything else, they very likely destroyed their own gametophytes as well.

\section{Acknowledgments}

For contributing specimens and locality data, we wish to thank Mr. and Mrs. Harry Cleaveland, Stan Jones, and Mr. and Mrs. Frank Lemon, Dr. D. A. Medlyn, Paul Rechten, Dr. J. Roth, A. D. Simper, Dr. W. L. Stokes, J. B. Sanchez, Dr. W. Shadish, James Stichka, Leslie Smith, Dr. G. Thayn, and Mrs. Marian Whitehead. Special thanks are extended to Dr. Charles Beck of the University of Michigan and Dr. Francis Hueber of the Smithsonian Institution for lending holotypes of the various North American species of Tempskya, to Dr. E. M. V. Nambudiri of the Energy Research Unit of the University of Regina for analyzing the carbonaceous shales and coalified material at the Castle Dale site, to Dr. S. R. Ash of Weber State University and to Dr. A. T. Cross of Michigan State University for reviewing the manuscript, and to Dr. Lee Parker of California Polytechnic State University for his assistance with some of the research on this fossil material.

\section{Literature cited}

Andrews, H. N., and E. M. Kern. 1947. The Idaho tempskyas and associated fossil plants. Ann. Mo. Bot. Gard. 34(2):119-183.

Arnold, C. A. 1945. Silicified plant remains from the Mesozoic and Tertiary of western North America. I. Ferns. Michigan Acad. Sci., Arts Letters Pap. 1944, 30:3-34.

- 1958. A new Tempskya. Contrib. Mus. Paleontol. Univ. Michigan 14(8): 133-142.

Ash, S. R., and C. B. Read. 1976. North American species of Tempskya and their stratigraphic significance. U.S. Geol. Surv. Prof. Pap. 847:1-42.

Bonefante-Fasolo, P. 1984. Anatomy and morphology of VA mycorrhizae. Pages 5-33 in C. L. Powell and D. J. Bagyaraj, eds. VA mycorrhiza. CRC Press, Boca Raton, $\mathrm{Fla}$.

Boodle, L. A. 1895. Spores in a specimen of Tempskya (Endogenites). Ann. Bot. 9:137-141.

Brown, R. W. 1950. Cretaceous plants from southwestern Colorado. U.S. Geol. Surv. Prof. Pap. 221-D:45-66.

Casagrande, D. J. 1987. Sulphur in peat and coal. Pages $87-$ 105 in A. C. Scott, ed. Coal and coal-bearing strata. Recent Advances, Geological Society Special Publication no. 32. Geological Society of America, Boulder, Colo.
Chandler, M. E. J. 1968. A new Tempskya from Kent. Br. Mus. (Nat. Hist.) Bull., Geol. 15(4):169-179.

Cichan, M. A., and T. N. Taylor. 1982. Wood-borings in Premnoxylon: plant-animal interactions in the Carboniferous. Palaeogeogr. Palaeoclimatol. Palaeoecol. 39:123127.

Cohen, A. W., W. Spackman, and R. Raymond, Jr. 1987. Interpreting the characteristics of coal seams from chemical, physical, and petrographic studies of peat deposits. Pages 107-125 in A. C. Scott, ed. Coal and coal-bearing strata. Recent Advances, Geological Society Special Publication no. 32. Geological Society of America, Boulder, Colo.

Corda, A. J. C. 1845. Beiträge zur Flora der Vorwelt. J. G. Calv'sche, Prague. (See p. 87, pl. 47, fig. 7.)

Crabtree, D. R. 1987. Angiosperms of the northern Rocky Mountains: Albian to Campanian (Cretaceous) megafossil floras. Ann. Mo. Bot. Gard. 74:707-747.

Creber, G. T. 1977. Tree rings: a natural data-storage system. Biol. Rev. (Lond.) 52:349-383.

Creber, G. T., and W. G. Chaloner. 1985. Climatic indications from growth rings in fossil woods. Pages 49-74 in P. J. Benchley, ed. Fossils and climate. Special issue of the Geological Journal. Wiley, New York. 
Cross, A. T., E. B. Maxfield, E. Cotter, and C. C. Cross. 1975. Field guide and road log to the western Book Cliffs, Castle Valley and parts of the Wasatch Plateau. Brigham Young Univ. Geol. Stud. 22(2):1-132 (See p. 173-174.)

Hall, I. R. 1984. Taxonomy of VA mycorrhizal fungi. Pages 57-94 in C. L. Powell and D. J. Bagyaraj, eds. VA mycorrhiza. CRC Press, Boca Raton, Fla.

Häntzchel, W., F. El-Baz, and G. C. Amstutz. 1968. Coprolites, an annotated bibliography. Mem. Geol. Soc. Am. 108:1-132.

Harley, J. L., and S. E. Smith. 1983. Mycorrhizal symbiosis. Academic Press, New York.

Hlustik, A. 1990. Bohemian biographies III: the story of Tempskya. IOP Newsl. 42:12-13.

Jackson, R. M., and P. A. Mason. 1984. Mycorrhiza. Edward Arnold, Baltimore,

Katich, P. J., Jr. 1951. Recent evidence for Lower Cretaceous deposits in Colorado Plateau. Am. Assoc. Pet. Geol. Bull. 35(19):2093-2094.

- 1952. Occurrence of Tempskya in the Lower Cretaceous of the Western Interior (Utah). J. Paleontol. 26: 677.

McKnight, K. H., and J. K. Rigby. 1963. Lower Cretaceous Tempskya from eastern Utah (abstract). Geol. Soc. Am. Spec. Pap. 73:91.

Nelson, M. E., and D. M. Crooks. 1987. Stratigraphy and paleontology of the Cedar Mountain Formation (Lower Cretaceous), eastern Emery County, Utah. Pages 55-63 in W. R. Averett, ed. Paleontology and geology of the Dinosaur Triangle. Guidebook 1987. Museum Western Colorado (publisher), Grand Junction, Colo.

Nishida, H. 1986. A new Tempskya stem from Japan. Trans. Proc. Paleontol. Soc. Jpn., N.S., 143:435-446.

Ogura, Y. 1927. Comparative anatomy of Japanese Cyatheaceae. J. Fac. Sci. Imp. Univ. Tokyo, Bot. 1:141-350.

Parrish, J. T., A. M. Ziegler, and C. R. Scotese. 1982. Rainfall patterns and the distribution of coals and evaporites in the Mesozoic and Cenozoic. Palaeogeogr. Palaeoclimatol. Palaeoecol. 40:67-101.

Read, C. B. 1939. The evolution of habit in Tempskya. Lloydia 2(1):63-72.

Read, C. B., and R. W. Brown. 1937. American Cretaceous ferns of the genus Tempskya. U.S. Geol. Surv. Prof. Pap. 186-F:105-131.

Read, D. J. 1983. The biology of mycorrhiza in the Ericales. Can. J. Bot. 61(3):985-1004.

Rothwell, G. W., and A. C. Scott. 1983. Coprolites within marattiaceous fern stems (Psaronius magnificus) from the Upper Pennsylvanian of the Appalachian Basin. Palaeogeogr. Palaeoclimatol. Palaeoecol. 41:227-232.

Rushforth, S. R. 1970. Notes on the fern family Matoniaceae from western United States. Brigham Young Univ. Geol. Stud. 16:3-34.

. 1971. A flora from the Dakota Sandstone Formation (Cenomanian) near Westwater, Grand County, Utah. Brigham Young Univ. Sci. Bull. 14:1-44.

Rushforth, S. R., and W. D. Tidwell. 1968. Notes on the distribution and morphology of the fern genus Astralopteris. Brigham Young Univ. Geol. Stud. 15:109-113.
Seward, A. C. 1899. On the structure and affinities of $\mathrm{Ma}$ tonia pectinata $\mathrm{R}$. Br., with notes on the geological history of the Matoniaceae. Philos. Trans. R. Soc. Lond. B 191: 171-209.

1923. The use of the microscope in palaeobotanical research. J. R. Microsc. Soc. 43:299-302.

-1924. On a new species of Tempskya from Montana, Tempskya knowltonii, sp. nov. Ann. Bot. 38:485-507.

Spackman, W., Jr. 1948. A dicotyledonous wood found associated with the Idaho tempskyas. Ann. Mo. Bot. Gard. 35:107-116.

Stach, E., M. Mackowsky, M. Teichmüller, G. H. Taylor, D. Chandra, and R. Teichmüller. 1982. Stach's textbook of coal petrology, 2d ed. Gebrüder Borntraeger, Berlin. 535 pp.

Stokes, C., and P. B. Webb. 1824. Descriptions of some fossil vegetables of the Tilgate Forest in Sussex. Geol. Soc. London Trans., 2d ser., 1:423-426.

Stokes, W. L. 1952. Lower Cretaceous in Colorado Plateau. Am. Assoc. Pet. Geol. Bull. 36:1766-1776.

Thayn, G. F., and W. D. Tidwell. 1984. Flora of the Lower Cretaceous Cedar Mountain Formation of Utah and Colorado. II. Mesembrioxylon stokesi. Great Basin Nat. 44: $257-262$.

Thayn, G. F., W. D. Tidwell, and W. L. Stokes. 1983. Flora of the Lower Cretaceous Cedar Mountain Formation of Utah and Colorado. I. Paraphyllanthoxylon utahense. Great Basin Nat. 43:294-402.

1985. Flora of the Lower Cretaceous Cedar Mountain Formation of Utah and Colorado. III. Icacinoxylon pittiense $\mathrm{n}$. $\mathrm{sp}$. Am. J. Bot. 72:175-180.

Tidwell, W. D. 1966. Cretaceous paleobotany of eastem Utah and western Colorado. Utah Geol. Min. Surv. Bull. 80:87-95.

Tidwell, W. D., B. Britt, and S. Robinson. 1983. Paleoecology of a small Lower Cretaceous swamp near Ferron, Utah. Geol. Soc. Am. Abstr. 15:286.

Tidwell, W. D., and N. Hebbert. 1972. Tempskya from the Cedar Mountain Formation near Moab, Utah. Geol. Soc. Am. Abstr. 4(6):417-418.

. 1976. Tempskya from the Lower Cretaceous Cedar Mountain Formation, Utah. Am. J. Bot. Abstr. 63(6):33.

Tidwell, W. D., S. R. Rushforth, and J. L. Reveal. 1967. Astralopteris, a new Cretaceous fern genus from Utah and Colorado. Brigham Young Univ. Geol. Stud. 14:237-240.

Tidwell, W. D., and G. F. Thayn. 1985. Flora of the Lower Cretaceous Cedar Mountain Formation of Utah and Colorado. IV. Palaeopiceoxylon thinosus (Protopinaceae). Southwest. Nat. 30(4):525-532.

Tidwell, W. D., G. F. Thayn, and J. L. Roth. 1976. Cretaceous and Early Tertiary floras of the Intermountain Area. Brigham Young Univ. Geol. Studies 22:77-98.

Tschudy, R. H., B. D. Tschudy, and L. C. Craig. 1984. Palynological evaluation of Cedar Mountain and Burro Canyon Formations, Colorado Plateau. U.S. Geol. Surv. Prof. Pap. 1281:1-24.

Worbes, M. 1989. Growth rings, increment and age of tree in inundation forests, savannas and a mountain forest in the neotropics. IAWA Bull., N.S., 10(2):109-122. 